\title{
The Impact of Foreign Language Learning on Foreign Language Teaching
}

\section{Claire Murray \\ Nara Medical University}

\section{Paul Mathieson \\ Nara Medical University}

\section{Francesco Bolstad}

Nara Medical University

\section{Reference Data}

Murray, C., Mathieson, P., \& Bolstad, F. (2021). The impact of foreign language learning on foreign language teaching. In P. Clements, R. Derrah, \& P. Ferguson (Eds.), Communities of teachers \& learners. JALT. https://doi.org/10.37546/JALTPCP2020-10

Can learning a foreign language make you a better foreign language teacher? This practiceoriented paper discusses the advantages of EFL teachers learning beginner-level French as a foreign language (FFL) for teacher development. In this paper, the authors, the teacher, a student, and the administrator of the FFL class, summarize the implementation and structure of this ongoing FFL class and describe the benefits and goals of the class for professional development. To better understand the efficacy of foreign language learning on EFL teaching, the authors consider how this class reflects current practices and research in the field of professional development. These reflections are further supported by the participants' personal experiences collected through two qualitative class surveys. The preliminary results indicate that the FFL class was beneficial for those involved and helped the participants to improve personally and professionally; limitations and potential future improvements to the course are also discussed.

外国語を学ぶことによって教師はより良い外国語教師になれるのか?本研究では、教師の育成を目的として、初級レベルの フランス語(FFL)を学ぶことでもたらされる効果を検証した。本論では、FFLクラスの教師、学生、および管理者が進行中のクラ
スの実施状況と構造をまとめ、専門能力開発の為の利点と目標を論じた。ままた、当該クラスの効果を検証するために、開講の 狙いとクラスに対する2回の質的調査結果を比較し分析を行った。その結果、FFLクラスはすべての目標を少なくとも部分的に 達成したという点で有益である一方、参加者の時間と作業負荷への影響が重大な課題であることが明らかになった。

R esearch strongly suggests that professional and personal development plays - an essential role for teachers. Previous studies have shown that professional development can lead to tangible improvements in student outcomes (Timperley, 2008) and improvements in both the teaching and learning environment (Jarzabkowski, 2002). One of the key benefits of professional development in an educational setting is the positive effects that social and team-building activities can have on teacher job satisfaction and collegial relationships (Edmonds, 2009; Shah, 2012). However, the need for the professional development of part-time teaching faculty is often ignored by universities (Bojarczyk, 2008; Masri, 2018). One of the reasons for this is the perception that these activities can involve a significant commitment from both the teachers and the administration regarding the time and resources required (Ajayi-Ore, 2020). In this paper, we discuss why implementing a foreign language class for the EFL teachers and staff of a university can provide participants with a professional development activity that is both enjoyable and beneficial.

The benefits of foreign language learning for foreign language teachers is an under-researched area of professional development. This paper addresses this gap by summarizing the ongoing efforts of an English department in a medical university in Japan to deliver faculty development through a beginner-level French as a foreign language (FFL) class. The FFL class was set up to address the lack of professional and personal development opportunities for both full-time and part-time teachers at universities, both in general (e.g., Masri, 2018) and in the department. The impetus for using language learning as a professional development activity for EFL teachers stems from studies into the classroom practices of language teachers. These studies show that university teachers draw upon a varied repertoire of knowledge and prior experiences 
when teaching (Oleson \& Hora, 2014). In particular, the language learning experiences of foreign language teachers have been shown to have a significant impact on their ideas on how languages should be taught and their pedagogical practices in the classroom (Borg, 2003). It was felt that providing teachers with their own language learning experience would help them better understand learning a language from their students' perspectives and provide them with a unique and interesting way to engage in a professional development activity with their colleagues.

Firstly, this paper outlines the participants, structure, and goals of the class. We then take a closer look at why participating in a foreign language would provide teachers with a valuable professional development experience. This includes examining the experiences of the participants in this program, and their perceptions of the positive and negative impacts of learning a foreign language as a professional development activity. The paper concludes with a discussion of some of the challenges involved with implementing this professional development activity and some practical steps that teachers and administrators can take to set up a similar professional development opportunity in their own department.

\section{Introduction to the Class}

When the English department decided to offer an FFL class to its teachers and staff, they wanted to create a professional development opportunity that both the teachers and staff would feel comfortable engaging in. According to Elliot et al. (2015), there are a few key points universities should consider when undertaking professional development programs for teaching staff, especially part-time staff, for example, avoiding scheduling conflicts with working hours and travel limitations, as well as providing a program that is seen as beneficial by the participants. Because of this, the class was developed in a way to ensure that it was both useful and as easy as possible for those interested in the class to participate in it. To ensure that the cost of the class would not deter participants from joining, the FFL class was offered free of charge for participants. In order to maximize the potential team-building effects of the class, it was open to all staff of the English department, including non-teaching staff. To balance the potential benefits of the class with the time commitment required, it was held for 1 hour twice a week. Participants were told that it was preferable for them to join both classes, but those who were not able to join both were able to attend once a week. The classes were also scheduled during the semester during a department-wide free period to ensure teachers who were interested in participating could do so without having to make additional trips to campus. Given that some of the potential participants had not studied French before, the course that was offered was a beginner-level language course. Finally, while participation was encouraged and every attempt was made to ensure that teachers who were interested in participating could do so, participation in the course was optional, and there was no penalty to the teachers who were not interested or able to attend.

\section{Goals of the Class}

As the primary purpose of the course was professional development, the FFL class was developed with six goals in mind. The goals of the class were divided into two categories: personal and team development, and professional development. The goals and their descriptions are shown in Table 1.

Table 1

Goals of the FFL Class

\begin{tabular}{|c|c|c|c|}
\hline & Goal & Description & $\begin{array}{c}\text { Type of } \\
\text { development }\end{array}$ \\
\hline 1 & Learn French & $\begin{array}{l}\text { Provide the opportunity for staff to learn } \\
\text { another language }\end{array}$ & \multirow{3}{*}{$\begin{array}{l}\text { Personal/team } \\
\text { development }\end{array}$} \\
\hline 2 & $\begin{array}{l}\text { Encourage team } \\
\text { building }\end{array}$ & $\begin{array}{l}\text { Provide staff with the opportunity to } \\
\text { exchange ideas and to work together in } \\
\text { pursuit of a shared learning goal }\end{array}$ & \\
\hline 3 & Have fun & $\begin{array}{l}\text { Provide staff with an opportunity to } \\
\text { meet and socialize outside of regular } \\
\text { teaching and working times }\end{array}$ & \\
\hline 4 & $\begin{array}{l}\text { Reflect on teaching } \\
\text { and learning beliefs }\end{array}$ & $\begin{array}{l}\text { Provide an opportunity for staff to reflect } \\
\text { on their teaching and learning beliefs }\end{array}$ & \multirow{3}{*}{$\begin{array}{l}\text { Professional } \\
\text { development }\end{array}$} \\
\hline 5 & $\begin{array}{l}\text { Promote practical } \\
\text { language teaching } \\
\text { skills }\end{array}$ & $\begin{array}{l}\text { Provide staff with practical examples of } \\
\text { language teaching }\end{array}$ & \\
\hline 6 & $\begin{array}{l}\text { Understand the } \\
\text { student perspective }\end{array}$ & $\begin{array}{l}\text { Provide staff with the opportunity to } \\
\text { develop empathy for their students } \\
\text { through foreign language learning }\end{array}$ & \\
\hline
\end{tabular}


The three personal and team development goals were designed to improve the participants' personal and collegial satisfaction, whereas the three professional development goals were chosen to focus on the potential pedagogical benefits participants would gain by participating in the class. All the goals, except the first, were included because of their potential positive effect on the teachers and the positive impact this would have on the students' learning environment. The first goal, learning French, was included because the class was a French language class, and it was felt that this type of tangible goal would help motivate teachers to participate in the course.

\section{The Participants}

In semester one, all the staff members of the English department attended the FFL class. There were seven participants, 6 teachers and 1 non-teaching staff member Three of the participants were only able to attend once a week. The participants had all had previous second language and foreign language teaching and learning experiences, with all of the participants reporting achieving between the CEFR B1 and C2 levels of proficiency in at least one second or foreign language. The self-reported French proficiency of the participants ranged from absolute beginner to CEFR B2. The participants reported spending between 0 and 60 minutes a week outside of class preparing for the class, with the majority spending 30 minutes a week. In semester two, three staff members, all teachers, attended the FFL class. One participant only attended once a week. A survey was given at the end of each semester in order to better understand the participants' opinions of the class and as means of improving the class as it continued (see the Appendix for the survey questions).

\section{Personal Goals}

\section{Learn French}

The overt goal of this class (learning French) was important to include for the participants because having a clear focus for a professional development activity has been shown to help motivate participants, which makes them more likely to engage in the professional development activity (Timperley et al., 2007). Due to the absolute beginner level of some of the participants, English was the language of instruction for the FFL class. However, every class included communication activities in which participants were expected to speak French. At the end of the first semester, all of the participants gave a short presentation introducing themselves and their families entirely in French and were able to answer straightforward questions related to these topics. From the teacher's perspective, the participants successfully learned some French, especially the beginner and elementary level participants.

More importantly, from a professional development perspective, nearly all of the participants reported greater confidence in their French language ability and felt that the class had been beneficial for this reason. The positive comments about the language learning aspect of the course included comments such as "[I] was able to learn French finally", and "It has been good to learn some French." While gauging the actual progress that the participants made is beyond the scope of this paper, the fact that many of the participants chose to comment on the fact that they were happy to be able to improve their French shows that having this type of tangible goal may help the participants to engage with the professional development activities of the FFL class. However, in the surveys given at the end of each semester, the participants reported that their main reason for taking the FFL class was to learn French (and not to engage in professional development). Seeing as learning French was by no means the primary goal from an administrative perspective, this may indicate that the other five goals of the FFL class were not communicated clearly enough to the participants.

\section{Encourage Team Building}

One of the most important benefits of professional development is that it has been shown to encourage team building. Studies have shown that teachers engaging in teambuilding activities benefit both teachers and students. For example, when interviewing the administration and teachers at seven different schools in the USA, Edmonds (2009) found that the majority of both the school administrators and the teachers felt that team-building activities at schools were necessary for open communication and building a positive working environment. Furthermore, all of the administrators who took part in her study and the majority of the teachers in her focus group interviews commented that they felt that team-building activities, both between teachers and between teachers and the administration, were vital for improving the morale of both the teachers and the students at their school. Strong collaboration and healthy collegiality among teaching colleagues have also been shown to be essential for improved student learning. In her study of two school districts in the USA, Datnow (2011) found that collaboration among teachers was a critical component in creating the type of learning environment necessary to focus on improving learner achievement. She noted that this type of collaboration requires constant communication between teachers, something that professional development activities focusing on team building can help to facilitate. Finally, Shah 
(2012) found that team building played a vital role in augmenting teacher professional growth, development, and job satisfaction.

Accordingly, team building was included as a goal for the FFL class to promote collegiality among staff by providing the opportunity for staff (including nonteaching staff) to get to know each other better and to work towards a shared goal together. In order to promote team building, Edmonds (2009) recommends games and communication activities that allow colleagues to learn more about "the whole person" instead of simply their work disposition. Accordingly, the FFL class was designed with a focus on communication activities and games. Participants were often put in pairs to practice a new grammar point or vocabulary set, and the teacher made a point of rotating the partners, so all participants had an opportunity to talk with each other. As the class met weekly, participants were able to engage multiple times with their colleagues in a more relaxed atmosphere and talk about non-work-related topics.

For the participants in the class, the ability to build connections with their colleagues and work on team building was one of the key benefits that they felt that they took from the course. In the end-of-semester surveys, multiple participants commented on this as being one of the main positive aspects of taking the FFL classes. These included comments such as, the class was a "Nice time to spend with my colleagues" and "I connected with my fellow teachers." As it can often be difficult to find the time and opportunity to converse with colleagues at Japanese universities, especially for part-time staff, this opportunity for team building was an important part of the program. However, due to the fact that four of the participants did not continue taking the class in the second semester, the opportunities for team building may not have been as beneficial during the second semester. One of the participants noticed this and commented that "The drop off in student numbers" was one of the negative aspects of the second semester. Given the importance of team building for professional development activities, in the future, it would be beneficial to see what could be done to accommodate more participants in an attempt to alleviate the decrease in participant numbers.

\section{Professional Goals}

Understand the Student Perspective

The goal of understanding students' perspectives was included as research has shown the importance of increasing teacher empathy as a means of improving student achievement (e.g., Liew et al., 2010; Tettegah \& Anderson, 2007). This was considered to be especially important at this medical university as the students have a heavy workload.
First-year students take between 20 and 30 hours of class a week, of which English comprises 3 hours. In an informal poll of 54 1st-year students at the medical university, 54\% reported English as being their most difficult class. Furthermore, if students fail a single core class (of which English is one), they must repeat the class and they cannot progress onto the next year of medical studies. Therefore, it was felt that participation in a professional development activity such as learning FFL would help to remind the participants of the effects that time and workload restraints can have on language learning.

Teacher empathy is "the ability to express concern and take the perspective of a student” (Tettegah \& Anderson, 2007, p. 50). Multiple studies have shown that empathic and supportive teachers facilitate student learning and achievement. Regarding academic achievement, Liew et al. (2010) found in their study of 761 academically atrisk elementary school children that previously lower-achieving students performed as well as higher-achieving students if they had a supportive teacher; Pianta and Stuhlman (2004) found that a positive teacher-student relationship enhanced the student's ability for academic success. Noting that language students are at higher risk of learner anxiety, Karimi and Fallah (2021) studied the relationship between perceived teacher support, academic burnout, and shame within 306 Iranian university EFL learners. They found that emotional and affective support and attention from teachers can be vital for language learners' psychological and motivational health. By establishing safe learning environments and conveying messages of trust, care, warmth, and respect, teachers of EFL students can reduce their students' feelings of shame and increase their intrinsic motivation for studying EFL, both of which contribute positively to lowering student burnout (Karimi \& Fallah, 2021). Similarly, Piechurska-Kuciel's (2011) study of 621 secondary school EFL students found that students reported lower levels of learner anxiety when they felt they could rely on their teacher for advice and assistance, whereas students who felt they did not have teacher support reported higher levels of learner anxiety. Furthermore, these feelings of anxiety were found to correlate directly to academic achievement and the students who reported higher levels of teacher support evaluated their language levels more highly and received better grades.

With the medical students' high-stakes and busy learning environment in mind, the FFL class was designed in part to remind the participants of what it is like to be studying a foreign language as part of a busy and stressful schedule. Firstly, as the FFL class was held during normal working hours, participants were expected to adjust their schedules to accommodate the classes if they wished to attend. Furthermore, French was chosen as the language to be taught in the class (instead of Japanese) to give the participants 
the opportunity to learn a foreign language (instead of a second language) as this was closer to the language learning situation experienced by the majority of the students at this university. It was thought that holding classes on busy workdays, as well as learning French instead of Japanese would encourage the participants' empathy for their students

For the participants, the opportunity to improve their empathy for students was one of the main benefits that they felt that they had received from the course. In the surveys, multiple participants made comments such as "It allowed me to understand the students (sic) perspective" and "Definitely it has changed the way I empathize with students." Given the importance of teacher empathy and support on students' academic achievement and well-being, the success of the FFL in encouraging participants to understand their students' perspectives was a key achievement.

\section{Promote Practical Language Teaching Skills}

The goal of promoting teaching skills was included for the FFL class as a means of encouraging teachers to engage with new teaching ideas. Although there is a prevailing idea that teachers teach the way they were taught (Hattie, 2008), Timperley et al.'s (2007) review of 72 studies that assessed the effects of professional development on pre-tertiary level teachers shows that teachers can and do respond to new teaching ideas through professional development. Two main criteria that they highlighted in their review as necessary for successful professional development were that the participants had extended and multiple opportunities to process new ideas and that there was sufficient engagement with the professional development to allow the uptake of new ideas and activities (Timperley et al., 2007). Moreover, observation of actual classroom methods has been found to be one of the most effective methods for the development of teacher knowledge and behavior (Hattie, 2008).

The format of the FFL class was chosen with this research in mind. First, a language class was chosen as the medium of the professional development opportunity as the participants would mostly be language teachers, and it was thought that it would be most beneficial to them to observe and participate in a language class taught by an experienced language teacher. Second, by having a tangible focus for the professional development activity (learning French), it was thought that the participants would be engaged with the material both as a student learning French, and as a language teacher learning new teaching skills. Lastly, the class was scheduled to be held twice a week for 12-13 weeks per semester to give the participants multiple opportunities to observe the experienced foreign language teacher while being engaged as a student with the material over an extended period of time, Therefore, a language class seemed likely to be an effective method of introducing and practicing new language teaching skills.

English classes at this medical university are very content-heavy and have a tendency to be teacher-focused. The department wanted to reduce teacher-fronted classroom activities and increase communication-based activities in the English classes; therefore, the FFL class was designed to be communicative, student-focused and fun. Grammar points and vocabulary items were reviewed and practiced using online learning platforms such as Kahoot! and Quizlet as well as with traditional games such as bingo, vocabulary tic tac toe, and information gap activities. In particular, the need for scaffolding and for participants to have multiple practice opportunities were prioritised in the FFL class. Accordingly, participants were given many opportunities to practice grammar points and vocabulary items, and participants were always given time to brainstorm or prepare their ideas before starting a speaking activity. It was hoped that the participants would be able to incorporate the digital learning platforms and the communicative activities they were using in the FFL classes into their own English classrooms.

Participants reported in the surveys that learning new teaching skills and ideas was one of the key benefits that they felt they had gained by taking the FFL class. Comments such as "I enjoyed learning some of the approaches to teaching that the teacher used" and "I have started using quizlet (sic) and some other applications [the FFL teacher] introduced" indicate that participants incorporated new ideas and techniques into their teaching practices.

\section{Potential Challenges of the FFL Class}

A review of the benefits of the FFL class would not be complete without balancing them against any potentially negative impacts of the class. In the surveys, participants were asked what the negative aspects of taking the FFL class were. The main negative impacts of the class for both semesters were on participants' time and workload. Almost all of the participants mentioned lack of preparation time for the FFL class or difficulty in balancing work and study time as a negative point of taking the class. This, however, would indicate that goal six (understand the students' perspective) was being achieved. However, the impact on time and workload ultimately led to four participants quitting the class, which is not an option for the English language students at the university (unless they wish to quit the university as well). Given the potential benefit to teachers and students by participating in the FFL class, it would seem worthwhile to find some way to allow these participants to continue taking the class. 
From the administrator's point of view, the perception of the FFL class's main function as a language class, and not a professional development opportunity, indicates a failure to clearly explain the focus and expectations of the class. It may also have been a contributing factor in the four participants' decision to quit the class, as they perceived it as "only" a French class, and not as a professional development opportunity. This further indicates the need to clearly communicate and manage the expectations and goals behind such endeavors.

\section{Discussion}

It was found that, overall, taking the FFL class contributed to the participants' professional and personal development. The key benefits for the participants were: learning French, bonding with colleagues, increasing teacher empathy, and learning new teaching skills. Based on these preliminary results we believe that it is worth continuing the FFL class for the remaining participants, and worth encouraging wider uptake of the class.

However, there are two potential limitations with the study described in this paper. Firstly, this study analyzed only a small number of participants over the course of two semesters. Therefore, it is impossible to make a generalizable conclusion about the benefit of foreign language learning based just on this study. Additionally, professional development success in teaching is defined not in terms of teacher mastery of new strategies but in terms of the effect that strategy has on student outcomes (Timperley, 2008). No research was done on the impact of student outcomes on students taught by these teachers. This is an area that is worthy of further exploration.

\section{Conclusion}

Given the amount of evidence that suggests professional development is beneficial for teachers, and the amount of influence professional development can have in the classroom, the conclusion that foreign language learning is an effective method of professional and team development may be of particular interest to university and department administrators. However, the benefits of professional development must, of course, be weighed against the cost in terms of both time and money. It is perhaps here that non-English foreign language classes as a form of professional development can truly shine. As English departments may already include teachers who possess both the linguistic and pedagogic skills necessary to teach a foreign language, it may be possible for such professional development programs to be instituted with a minimum amount of cost to the department, both in terms of money and time. It is our belief that this is a worthwhile activity for other English departments to consider pursuing.

\section{Bio Data}

Claire Murray has a French degree from McMaster University, Canada, and holds an MA in Applied Linguistics from the University of Birmingham, UK. She has taught ESL/EFL to a wide range of students in New Zealand and Japan and is currently an ESP lecturer in the Department of Clinical English at Nara Medical University. Her primary research interests are learning strategies and vocabulary acquisition. <c.murray@naramed-u.ac.jp>

Paul Mathieson has been teaching English in Japan since 2006. He is an associate professor in the Department of Clinical English at Nara Medical University, where he is the co-ordinator of the nursing English programme. He has law and arts degrees from the University of Auckland, New Zealand, and has an MA in Applied Linguistics and TESOL from the University of Leicester, UK. His primary research interests are vocabulary acquisition, ESP, and learner motivation. <mathieson@naramed-u.ac.jp>

Francesco Bolstad is a professor and head of the Department of Clinical English at Nara Medical University. He coordinates a range of CLIL clinical English courses and a diverse team of teachers dedicated to a collaborative teaching approach. He is a New Zealandqualified biology, technology, and economics teacher with over 25 years of teaching experience spanning a plethora of teaching environments, ages, and subjects. Francesco is interested in CLIL, ESP, and teacher education research. <bolstad@naramed-u.ac.jp>

\section{References}

Ajayi-Ore, L. O. (2020). Teaching prowess and pedagogical effectiveness of adjunct faculty (Publication No. 28026821) [Doctoral dissertation, University of Pennsylvania]. ProQuest Dissertations \& Theses Global. https://www.proquest.com/docview/2447270260

Bojarczyk, H. (2008). Faculty development activities for new adjunct faculty: A qualitative investigation of which types of activities most benefit new adjunct faculty at four-year colleges and universities (Publication No. 3333061) [Doctoral dissertation, Oakland University]. ProQuest Dissertations \& Theses Global. https://www.proquest.com/docview/304414793

Borg, S. (2003). Teacher cognition in language teaching: A review of research on what language teachers think, know, believe, and do. Language Teaching, 36(2), 81-109. https://doi.org/10.1017/ s0261444803001903 
Datnow, A. (2011). Collaboration and contrived collegiality: Revisiting Hargreaves in the age of accountability. Journal of Educational Change, 12(2), 147-158. https://doi.org/10.1007/s10833011-9154-1

Edmonds, N. A. (2009). Improving teacher morale with team building [Doctoral dissertation, East Tennessee State University]. Digital Commons @ East Tennessee State University. https:// dc.etsu.edu/etd/1853

Elliot, M., Rhoades, N., Jackson, C. M., Mandernach, B. J. (2015). Professional development: Designing initiatives to meet the needs of online faculty. Journal of Educators Online. 12(1), 160188. https://doi.org/10.9743/jeo.2015.1.2

Hattie, J.A.C. (2008). Visible learning: A synthesis of over 800 meta-analyses relating to achievement. Routledge. https://doi.org/10.4324/9780203887332

Jarzabkowski, L. M. (2002). The social dimensions of teacher collegiality. The Journal of Educational Enquiry, 3(2), 1-20. https://ojs.unisa.edu.au/index.php/EDEQ/article/view/538

Karimi, M. N., \& Fallah, N. (2021). Academic burnout, shame, intrinsic motivation and teacher affective support among Iranian EFL learners: A structural equation modeling approach. Current Psychology, 40, 2026-2037. https://doi.org/10.1007/s12144-019-0138-2

Liew, J., Chen, Q., \& Hughes, J. N. (2010). Child effortful control, teacher-student relationships, and achievement in academically at-risk children: Additive and interactive effects. Early Childhood Research Quarterly, 25(1), 51-64. https://doi.org/10.1016/j.ecresq.2009.07.005

Masri, T. I. (2018). The professional identity of adjunct faculty: Exploratory study at a private university in the UAE. English Language Teaching, 11(10), 16-29. https://doi.org/10.5539/elt. v11n10p16

Oleson, A., \& Hora, M. T. (2014). Teaching the way they were taught? Revisiting the sources of teaching knowledge and the role of prior experience in shaping faculty teaching practices. Higher Education, 68(1), 29-45. https://doi.org/10.1007/s10734-013-9678-9

Pianta, R. C., \& Stuhlman, M. W. (2004). Teacher-child relationships and children's success in the first years of school. School Psychology Review, 33(3), 444-458. https://doi.org/10.1080/02796015. 2004.12086261

Piechurska-Kuciel, E. (2011). Perceived teacher support and language anxiety in Polish secondary school EFL learners. Studies in Second Language Learning and Teaching, 1(1), 83-100. https://doi. org/10.14746/ssllt.2011.1.1.5

Shah, M. (2012). The importance and benefits of teacher collegiality in schools-A literature review. Procedia - Social and Behavioral Sciences, 46, 1242-1246. https://doi.org/10.1016/j. sbspro.2012.05.282

Tettegah, S., \& Anderson, C. J. (2007). Pre-service teachers' empathy and cognitions: Statistical analysis of text data by graphical models. Contemporary Educational Psychology, 32(1), 48-82. https://doi.org/10.1016/j.cedpsych.2006.10.010
Timperley, H., Wilson, A., Barrar, H., \& Fung, I. (2007). Teacher professional learning and development: Best evidence synthesis iteration. New Zealand Ministry of Education. https://www. educationcounts.govt.nz/_data/assets/pdf_file/0017/16901/TPLandDBESentireWeb.pdf

Timperley, H. (2008). Teacher professional learning and development (Educational Practices Series. Number 18). International Academy of Education. http://www.ibe.unesco.org/fileadmin/user upload/Publications/Educational_Practices/EdPractices_18.pdf

\section{Appendix}

Survey for Semester One (for multiple-choice questions, the possible answers are given in brackets)

\begin{tabular}{|c|c|}
\hline 1.1 & Are you: (Female, Male) \\
\hline 1.2 & Select your age group: $(25-29,30-34,35-39,40-45,45-49,50-54)$ \\
\hline 1.3 & What is your first language? \\
\hline 1.4 & $\begin{array}{l}\text { How long have you taught English as a foreign language? (i.e., in a country } \\
\text { where English isn't commonly spoken) }\end{array}$ \\
\hline 1.5 & $\begin{array}{l}\text { How long have you taught English as a second language? (i.e., in a country } \\
\text { where English is spoken) }\end{array}$ \\
\hline 1.6 & Have you studied a foreign or second language? \\
\hline 1.7 & How long did you study the second or foreign language? \\
\hline 1.8 & $\begin{array}{l}\text { What level have you achieved in the second or foreign language? (Absolute } \\
\text { beginner, A1 Beginner, A2 Elementary, B1 Intermediate, B2 Upper Intermediate, } \\
\text { C1 Advanced, C2 Proficient) }\end{array}$ \\
\hline 1.9 & How long did you spend a week preparing or studying for the French class? \\
\hline 1.10 & $\begin{array}{l}\text { What was your level of French before the class started? (Absolute beginner, } \\
\text { A1 Beginner, A2 Elementary, B1 Intermediate, B2 Upper Intermediate, C1 } \\
\text { Advanced, C2 Proficient) }\end{array}$ \\
\hline $\mathrm{I} .11$ & Out of 26 classes, approximately how many did you attend? \\
\hline 1.12 & $\begin{array}{l}\text { I am pleased with the progress I made in French class. (Strongly agree, Agree, } \\
\text { Disagree, Strongly disagree) }\end{array}$ \\
\hline 1.13 & I enjoy studying French. (Strongly agree, Agree, Disagree, Strongly disagree) \\
\hline 1.14 & What have been the positive aspects of taking this French class? \\
\hline
\end{tabular}


I.15 What have been the negative aspects of taking this French class?

I.16 Why are you studying French?

I.17 I will continue taking this French class. (Yes, No (Please give a reason)

I.18 I have gained some insights into my behavior as a student (as a result of taking this French class). (Strongly agree, Agree, Disagree, Strongly disagree)

I.19 I have gained some insights into my behavior as a teacher (as a result of taking this French class). (Strongly agree, Agree, Disagree, Strongly disagree)

I.20 Has the experience of learning another language impacted you in the following areas at all? (Click on all that apply). (Beliefs about teaching, Beliefs about

learning, Beliefs about the ideal language classroom, Error correction methods, Empathy for students, Use of materials, Methods of giving feedback, Ideas about student motivation, Importance of pronunciation)

Survey for Semester Two (for multiple-choice questions, the possible answers are given in brackets)

\begin{tabular}{|l|l|}
\hline II.1 & Out of 20 classes, approximately how many did you attend? \\
\hline II.2 & $\begin{array}{l}\text { I am pleased with the progress I made in French class. (Strongly agree, Agree, } \\
\text { Disagree, Strongly disagree) }\end{array}$ \\
\hline II.3 & I enjoy studying French. (Strongly agree, Agree, Disagree, Strongly disagree) \\
\hline II.4 & What have been the positive aspects of taking this French class? \\
\hline II.5 & What have been the negative aspects of taking this French class? \\
\hline II.6 & How could the class be improved for you? \\
\hline II.7 & I will continue taking this French class. (Yes, No) \\
\hline II.8 & $\begin{array}{l}\text { If you answered yes to the previous question, what are your goals for the next } \\
\text { semester in this class? }\end{array}$ \\
\hline Il.9 & $\begin{array}{l}\text { How much time per week do you want to spend studying French outside of } \\
\text { class? }\end{array}$ \\
\hline II.10 & $\begin{array}{l}\text { I have gained some insights into my behavior as a student (as a result of taking } \\
\text { this French class). (Strongly agree, Agree, Disagree, Strongly disagree) }\end{array}$ \\
\hline II.11 & $\begin{array}{l}\text { I have gained some insights into my behavior as a teacher (as a result of taking } \\
\text { this French class). (Strongly agree, Agree, Disagree, Strongly disagree) }\end{array}$ \\
\hline
\end{tabular}

\section{II.12 Attitude / Beliefs Impact}

Has the experience of learning another language impacted your ideas or beliefs as a teacher? Please give examples with your answer below. (Beliefs about

teaching, Beliefs about learning, Beliefs about the ideal language classroom, Empathy for students, Use of materials, Methods of giving feedback, Ideas about student motivation, Importance of pronunciation)

\section{II.13 Practical Impact}

Has anything you learned in French class impacted how you teach your classes? Please give examples with your answer below. (Activities, Student Empathy, Feedback, Motivation, Use of materials, Classroom management) 